\title{
Growth hormone: isoforms, clinical aspects and assays interference
}

\author{
Júnia Ribeiro de Oliveira Longo Schweizer ${ }^{1}$, Antônio Ribeiro-Oliveira $\mathrm{Jr}^{1}$ and Martin Bidlingmaier ${ }^{2^{*}}$ (D)
}

\begin{abstract}
The measurement of circulating concentrations of growth hormone $(\mathrm{GH})$ is an indispensable tool in the diagnosis of both GH deficiency and GH excess. GH is a heterogeneous protein composed of several molecular isoforms, but the physiological role of these different isoforms has not yet been fully understood. The $22 \mathrm{KD} G H(22 \mathrm{~K}-\mathrm{GH})$ is the main isoform in circulation, followed by $20 \mathrm{KD}$ GH $(20 \mathrm{~K}-\mathrm{GH})$ and other rare isoforms. Studies have been performed to better understand the biological actions of the different isoforms as well as their importance in pathological conditions. Generally, the non- $22 \mathrm{~K}$ - and $20 \mathrm{~K}-\mathrm{GH}$ isoforms are secreted in parallel to $22 \mathrm{~K}-\mathrm{GH}$, and only very moderate changes in the ratio between isoforms have been described in some pituitary tumors or during exercise. Therefore, in a diagnostic approach, concentrations of $22 \mathrm{~K}-\mathrm{GH}$ accurately reflect total GH secretion. On the other hand, the differential recognition of $\mathrm{GH}$ isoforms by different $\mathrm{GH}$ immunoassays used in clinical routine contributes to the known discrepancy in results from different $\mathrm{GH}$ assays. This makes the application of uniform decision limits problematic. Therefore, the worldwide efforts to standardize GH assays include the recommendation to use $22 \mathrm{~K}$ GH specific GH assays calibrated against the pure $22 \mathrm{~K}-\mathrm{GH}$ reference preparation 98/574. Adoption of this recommendation might lead to improvement in diagnosis and follow-up of pathological conditions, and facilitate the comparison of results from different laboratories.
\end{abstract}

Keywords: Growth hormone, Growth hormone isoform, Growth hormone molecule, 22 k growth hormone isoform, 20 k growth hormone isoform, Acromegaly, Growth hormone deficiency, Growth hormone assays, IRP 98/574

\section{Background}

The measurement of circulating concentrations of growth hormone $(\mathrm{GH})$ is an indispensable tool in the diagnosis of both GH deficiency and GH excess. GH is a heterogeneous protein composed of several molecular isoforms, but the physiological role of the different isoforms has not yet been clarified. Owing to the fact that assays to specifically measure the different $\mathrm{GH}$ isoforms are not easily available, only a limited number of studies have investigated them under various clinical conditions. Most commercially available GH assays have not been fully characterized with respect to their cross-reactivity with the different isoforms. It must be assumed that most assays measure a mixture of isoforms with differences in affinity. This in part explains why despite some advances in design, practicability and sensitivity of the

\footnotetext{
* Correspondence: martin.bidlingmaier@med.uni-muenchen.de

${ }^{2}$ Endocrine Laboratory, Medizinische Klinik und Poliklinik IV, Klinikum der

Universität München, Ziemssenstraße 1, 80336 Munich, Germany

Full list of author information is available at the end of the article
}

assays, discrepancies between GH concentrations reported from different $\mathrm{GH}$ assays increased over the last decades [1-3]. This article reviews available information on the main $\mathrm{GH}$ isoforms as well as their impact on $\mathrm{GH}$ measurements in clinical practice.

\section{GH molecule}

Growth hormone belongs to a superfamily of cytokines, which includes interleukins, cytokines, as well as leukemic, neurotropic, and growth factors [4]. GH is a polypeptide hormone exhibiting molecular heterogeneity. It consists of a complex mixture of molecular isoforms and their multimers. In humans, the genetic locus that codes $\mathrm{GH}$ resides on chromosome 17q24.2 [4, 5], has 46.83 kilobases and contains five GH related genes. These multiple genes most likely arose from gene duplication. Each of these genes is composed of five exons and four introns: GH1 (or GH-N), GH2 (or GH-V), CS1, CS2 and CSL. While the GH1 is mainly expressed in somatotropes of the pituitary gland, the GH2 and CS (chorionic somatomammotropin also 
known as placental lactogen) are expressed exclusively by the placenta in females during pregnancy. The CSL (CS-like protein) is expressed at low levels and its function remains unclear [6].

\section{Pituitary GH - isoforms and fragments $22 \mathrm{~K}-\mathrm{GH}$}

The GH1 is expressed mainly in somatotrope cells of the pituitary gland. Expression in the immune system has been described, although there is no evidence that lymphocyte derived GH significantly contributes to circulating GH concentrations. The main product of this gene is a 191 amino acids single-chain protein stabilized by two disulphide bridges. The molecular weight is 22,129 Da [7]. This $22 \mathrm{~K}-\mathrm{GH}$ molecule is the main $\mathrm{GH}$ isoform, representing more than $90 \%$ of total $\mathrm{GH}$ in circulation. Its tertiary structure is a 4-helical (Fig. 1) twisted bundle with unusual connectivity. The helices run up-up-down-down instead of the more usual up-down-up-down form. There are two binding-sites interacting with the GH receptor, namely site I and site II. Spectrums of posttranslational modifications of this isoform, including acetylation, phosphorylation, deamidation and glycosylation have been described, which can potentially modify GH actions $[8,9]$. GH is best known from its growth promoting activity in children, but also has important biological activities in adults. These include lipolysis, glucose-, calcium- and phosphorous-metabolism as well as lactogenesis and immune function. The previous knowledge that some hormones and cleaved fragments have biological actions, like POMC (proopiomelanocortin), ACTH (adrenocorticotrophic hormone) and $\beta$-endorphin, as well as ANP (atrial natriuretic peptide) and BNP (brain natriuretic peptide), has led to the suspicion of $\mathrm{GH}$ isoforms existence and possible functions.

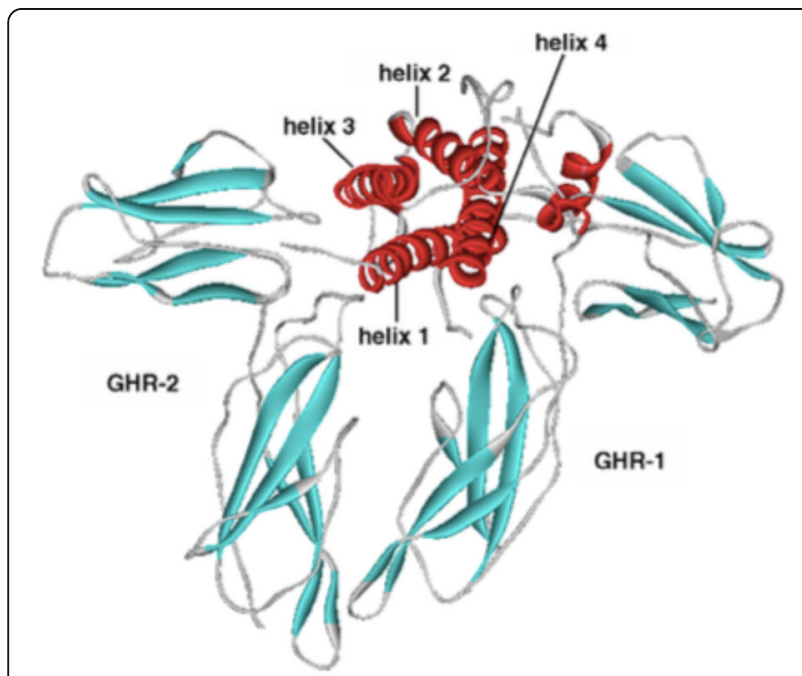

Fig. 1 The $22 \mathrm{~K}-\mathrm{GH}$ isoform structure and GH-R (GH receptor) biding sites (reproduced with permission from [19]

\section{$20 \mathrm{~K}-\mathrm{GH}$}

The second most abundant $\mathrm{GH}$ isoform is the $20 \mathrm{~K}-\mathrm{GH}$ molecule. It is derived from $\mathrm{GH}-1$ by alternative pre-messenger ribonucleic acid (pre mRNA) splicing of exon 3 . The structure is similar to $22 \mathrm{~K}-\mathrm{GH}$ except for a deletion of the internal residues 32-46 (Fig. 2). Therefore, $20 \mathrm{~K}-\mathrm{GH}$ consists of 176 amino acids only. The molecular weight is 20,274 Da. This smaller GH isoform represents about $10 \%$ of total circulating GH. There is controversy in the literature regarding the biological function of $20 \mathrm{~K}-\mathrm{GH}$ [10-13]. Most in vitro and animal studies report similar activities to promote growth and stimulate lipolysis, while some authors discussed reduced diabetogenic and anti-natriuretic activities [14-17]. The $20 \mathrm{~K}-\mathrm{GH}$ isoform is more prone to dimerize, leading to slower clearance when compared to $22 \mathrm{~K}-\mathrm{GH}$. This potentially could lead to a change in the relative abundance of $20 \mathrm{~K}$ - and $22 \mathrm{~K}-\mathrm{GH}$ isoforms in plasma over time following a secretory burst and possibly an extended action of the $20 \mathrm{~K}-\mathrm{GH}$ isoform. Since the residues 32-46 missing in the $20 \mathrm{~K}-\mathrm{GH}$ isoform overlap with the GH receptor binding site 1 (Figs. 1 and 2), the strength of interaction with the $\mathrm{GH}$ receptor could be different from the $22 \mathrm{~K}-\mathrm{GH}$ [14]. However, there is compelling evidence that both $22 \mathrm{~K}$ - and $20 \mathrm{~K}-\mathrm{GH}$ can activate Janus Kinase 2 (JAK2), signal transducers and activators of transcription 1, 3 and 5 (STATs 1/3/5), although the level of STAT $1 / 3 / 5$ phosphorylation induced by $22 \mathrm{~K}-\mathrm{GH}$ are higher than those of $20 \mathrm{~K}-\mathrm{GH}$ [18].

\section{GH fragments}

As aforementioned, although the $22 \mathrm{~K}-\mathrm{GH}$ is the main predicted protein product from the GH gene, posttranscriptional and posttranslational processing can lead to different $\mathrm{GH}$ isoforms. A number of such smaller fragments or isoforms has been described, but not all of them could be independently confirmed [10, 19]. It is important to realize that methodological differences in the experimental approach to identify these fragments as well as differences between species or matrices might explain the inconsistency of some findings. It has been reported that a single specific cleavage can generate two contiguous GH fragments of $5 \mathrm{~K}$ (fragment 1-43) and $17 \mathrm{~K}$ (fragment 44-191). These isoforms were synthesized and isolated from pituitary extract but have also been reported to occur in significant amounts in circulation. It has been suggested that $5 \mathrm{~K}-\mathrm{GH}$ has similarity with the GH N-terminal region, has insulin-like activity and can be an in-vitro substrate of dipeptidyl peptidase [20]. Independently, a polypeptide of $17.5 \mathrm{~K}$ resulting from $\mathrm{GH}$ exon 3 skipping has been described in pituitary and circulation, representing 1 to $5 \%$ of GH transcripts. It reportedly exists mainly under pathological conditions. However, identity to the above mentioned $17 \mathrm{~K}-\mathrm{GH}$ fragment 44-191 could not be demonstrated by the assay 


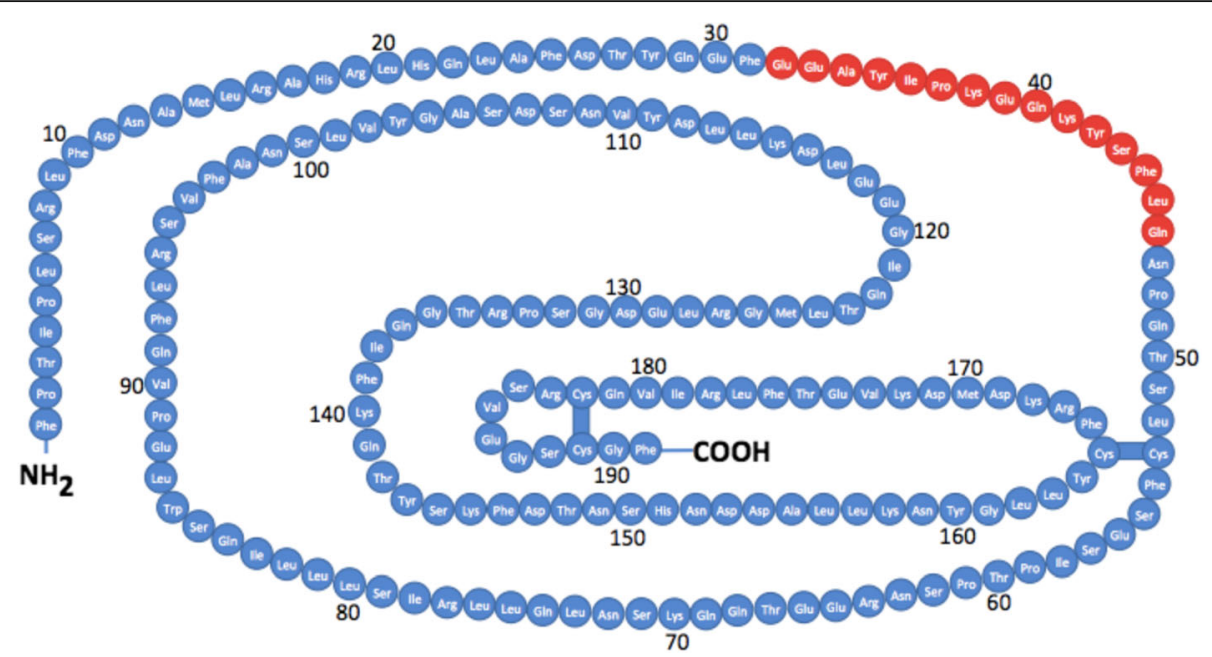

Fig. 2 The $22 \mathrm{~K}-\mathrm{GH}$ isoform molecule with 191 residues. The $20 \mathrm{~K}-\mathrm{GH}$ isoform has the same residues, except the $32-46$ residues, which are missing

used [21]. Another synthetic peptide obtained by stop sense molecular inclusion in the $\mathrm{GH}$ gene sequence (fragment 53-134) was also discussed to correspond to $17 \mathrm{~K}-\mathrm{GH}$ isoform. Other molecular variants including $12 \mathrm{~K}-\mathrm{GH}$, glycosylated $\mathrm{GH}$, deamidated $\mathrm{GH}$, and phosphorylated GH have also been described. However, more research is obviously needed to fully understand the nature of the smaller isoforms [7, 22-24].

At the other end of the molecular weight spectrum, larger forms of $\mathrm{GH}$ molecules can be found: $35 \mathrm{~K}-\mathrm{GH}$ and $45 \mathrm{~K}-\mathrm{GH}$, as well as $\mathrm{GH}$ homo- and hetero-dimers and -oligomers have been found [10, 19]. It is still uncertain whether these isoforms could have the same biological actions potency of the $22 \mathrm{~K}-\mathrm{GH}$. They may act as either $22 \mathrm{~K}-\mathrm{GH}$ agonists or antagonists, thus regulating biological functions of $\mathrm{GH}$.

In addition to naturally occurring $\mathrm{GH}$ isoforms, additional isoforms and fragments have been synthesized. Currently, the GH receptor antagonist pegvisomant is the most relevant example of an artificial GH isoform. The amino acid sequence differs from that of naturally occurring $22 \mathrm{~K}-\mathrm{GH}$ in only eight amino acids in binding site 1 (H18D, H21N, R167N, K168A, D171S, K172R, E174S, I179T), and one amino acid in binding site 2 (G120R). Also, pegylated residues were added to Lys residues in the $22 \mathrm{KD}-\mathrm{GH}$, producing a molecule with $42-46 \mathrm{~K}$. These targeted mutations led to the generation of a GH molecule which can bind to one GH receptor molecule by very high affinity but does not correctly bind to the other molecule of the dimeric $\mathrm{GH}$ receptor. This prevents signal transduction, making the molecule a potent $\mathrm{GH}$ antagonist used to the treatment of acromegaly [25-27].

Among the smaller GH molecules, which have been synthesized is GH 30-54 [19]. It contains the segment GH32-46, which distinguishes the two main GH isoforms, i.e. the $22 \mathrm{~K}$ - and $20 \mathrm{~K}-\mathrm{GH}$. Its presence in biological fluid and the biological effects are not known. Another fragment, GH 108-129, may be originated from natural biosynthesis or $\mathrm{GH}$ fragmentation. It encompasses the heli $\times 3$ and site-II regions, the latter related to $\mathrm{GH}$ receptor interaction. Since mutations in this site could result in GH receptor binding interference and ultimately in growth disruption, this peptide could potentially serve as another GH antagonist and has been patented. A fragment $147-191$ is obtained by enzymatic proteolysis and may be responsible for the generation of the fragment 177-191 (AOD9401). This late fragment is a short peptide, and one group has claimed it has GH like activity and the potential for treating obesity, due to its action on lipolysis $[28,29]$. Interestingly, many of the fragments first were theoretically hypothesized, and then produced later on [30]. However, the significance of all these products for routine treatment remains unclear.

\section{Placental GH}

The placental GH (GH2 or GH-V) shares similarity with GH1 gene, except for 13 residues difference. It contains a consensus sequence for $\mathrm{N}$-glycosylation at position 140, suggesting the existence of two GH2 isoforms: a glycosylated and a non-glycosylated form. The placental GH is a more basic protein, expressed exclusively in syncytiotrophoblast of the placenta. It is progressively released into the maternal circulation with peak concentrations reached in late pregnancy. Due to its high somatogenic activity, IGF-I concentrations in pregnant females tend to increase. In turn, these increasing IGF-I concentrations lead to an almost complete suppression of the pituitary GH-N secretion with advancing pregnancy. Although there is evidence of $20 \mathrm{~K}-\mathrm{GH}$ isoform derived from placental $\mathrm{GH}$, this gene is less prone of alternative splicing and does not represent 
the major origin of this isoform [31]. There is also evidence that placental derived $20 \mathrm{~K}-\mathrm{GH}$ has lower diabetogenic and lactogenic activities when compared to the placental $22 \mathrm{~K}-\mathrm{GH}$ [32]. Chorionic somatomammotropin (CS), the other important product of the GH gene family expressed in the placenta, has $85 \%$ structural homology with pituitary GH but does not have important somatogenic bioactivity. GH-V and CS will not be further discussed herein, as their importance are limited to the gestational period, which is not an objective of this article.

\section{GH isoform secretion in healthy and disease Physiology}

$22 \mathrm{~K}-\mathrm{GH}$ is secreted from the pituitary gland under hypothalamic control. Secretion is classically stimulated by GHRH and inhibited by somatostatin. 22 K-GH secretory pulses occur every $2-3 \mathrm{~h}$ with great amplitude variance. The largest pulses usually occur at night, during slow wave sleep [33]. The $22 \mathrm{~K}-\mathrm{GH}$ secretion pattern may differ between sexes, mainly due to estrogenic effect in females. Females usually have higher secretion rates, higher interpeak levels and more erratic secretion patterns of this isoform than males [34]. The $20 \mathrm{~K}-\mathrm{GH}$ isoform has been reported to be higher in females than males, although the ratio of 20 - to $22 \mathrm{~K}-\mathrm{GH}$ usually does not differ between sexes [35, 36]. $22 \mathrm{~K}-\mathrm{GH}$ secretion patterns also change with age. The $22 \mathrm{~K}-\mathrm{GH}$ peaks are higher in puberty, and secretion rates decrease later in life by approximately $15 \%$ per decade. Other factors also affect GH secretion: Obesity is known to attenuate GH secretion whereas physical activity, stress and fasting are acute stimuli. In physiological state, the $20 \mathrm{~K}-\mathrm{GH}$ and the $22 \mathrm{~K}-\mathrm{GH}$ isoforms are secreted in a pulsatile manner, in a constant molar ratio and the peaks from both isoforms were coincident in healthy individuals, although much lower for $20 \mathrm{~K}-\mathrm{GH}$ isoform [36].

Although there are other sites of GH clearance (e.g. the liver), the major portion of the metabolic clearance of monomeric GH occurs in the kidney. There is an efficient glomerular filtration and degradation in the proximal tubule. The urinary GH corresponds to only $1 /$ 10,000 th of glomerular filtered GH. Some studies reported differences in clearance of isoforms, with a slower clearance for oligomeric $\mathrm{GH}$ and $20 \mathrm{~K}-\mathrm{GH}$ compared to the main $22 \mathrm{k}$ isoform. One study demonstrated an approximately $30 \%$ reduced clearance for $20 \mathrm{~K}-\mathrm{GH}$ [37], although direct comparison of results from isoform specific assays might be difficult. There is little information about salivary $\mathrm{GH}$, but in normal subjects it seems to be 1000 -fold lower than serum GH. Since both, urinary and salivary GH are present in much smaller quantities than serum $\mathrm{GH}$, methods to assess $\mathrm{GH}$ in these matrices are difficult and less standardized. Urinary GH has also been shown to be less stable than serum GH.
Thus, it is no surprise the main matrix to measure $22 \mathrm{~K}$ and $20 \mathrm{~K}-\mathrm{GH}$, and also the main source of our knowledge about $\mathrm{GH}$ isoforms is serum.

\section{Exercise}

Exercise is a well-recognised condition that naturally stimulates GHRH and GH release in the circulation [38]. It can alter nocturnal GH secretion pattern by attenuating burst mass and amplitude, but increasing burst frequency. Therefore, the total nocturnal GH secretion is not altered [39]. Exercise can increase lactate acid, and there is a relation between GH secretion and blood lactate [39].

Some GH isoform studies measured various GH isoforms with distinct methods under different physical activity protocols. Wallace et al. [40] showed that all GH isoforms (22 K-, $20 \mathrm{~K}$ - and non-22 K-GH isoforms) increased during acute exercise. The $22 \mathrm{~K}-\mathrm{GH}$ (polyclonal immunoradiometric assay) was the main $\mathrm{GH}$ isoform produced during physical activity and peaked at $30 \mathrm{~min}$. The $20 \mathrm{~K}-\mathrm{GH}$ (ELISA) and the non $22 \mathrm{~K}-\mathrm{GH}$ measured by the $22 \mathrm{~K}-\mathrm{GH}$ exclusion assay exhibited a somewhat greater increase during the post exercise period. This temporarily increased the relative abundance of the non-22 K-GH isoforms. The authors suggested that these isoforms might play a role in preventing post-training hypoglycemia, as the $\mathrm{GH}$ isoforms could have diabetogenic effects. Another study [41] found a moderate modulation of $\mathrm{GH}$ isoforms after acute exercise. As expected, concentrations of $22 \mathrm{~K}-\mathrm{GH}$ (IFMA) and $20 \mathrm{~K}-\mathrm{GH}$ (specific ELISA) isoforms increased, but - in contrast to the above mentioned study - the increase was greater for $22 \mathrm{~K}-\mathrm{GH}$. Accordingly, in this study the ratio $22 \mathrm{~K}-/ 20 \mathrm{~K}-\mathrm{GH}$ was slightly increased for a short period after acute physical activity. After chronic resistance exercise, most studies did not find major alteration in different molecular weight $\mathrm{GH}$ isoforms [42]. However, in a study by Pierce et al. [43] it was shown that acute and chronic resistance exercise led to the appearance of similar amounts of disulphide-linked GH aggregates. The physiological significance of this alteration is unknown. Some studies used a very different analytical approach to study different molecular weight GH isoforms in physical activity. In these studies, $\mathrm{GH}$ isoforms were separated into categories greater than $60 \mathrm{~K}(>60 \mathrm{~K}), 30-60 \mathrm{~K}$ and less than $30 \mathrm{~K}(<30 \mathrm{~K})$. In females, acute heavy resistance exercise led to an increase in $30-60 \mathrm{k}$ and $>60 \mathrm{k}$, but not in the $<30 \mathrm{~K}$ molecular weight $\mathrm{GH}$ [44]. Before exercise, stronger women had greater total GH than the weaker ones, while the latter had higher smaller weight GH fractions ( $<30 \mathrm{~K})$. All GH isoforms increased after exercise in both, strong and weak untrained women, although the lower molecular weight variants were less responsive to greater amounts of exercise in stronger women [45]. The use of oral contraceptive (OC) in untrained women also seemed to influence the $\mathrm{GH}$ response during exercise when assessed by these assay methods, with 
higher abundance of high molecular weight $\mathrm{GH}$ in both resting and post exercise states in the OC group [46]. In contrast, other studies only confirmed that in the basal state all $\mathrm{GH}$ isoforms tend to be higher in females, but the $20 \mathrm{~K}-22 \mathrm{~K}-\mathrm{GH}$ ratio was not different between sexes. In addition, oral contraceptive administration to postmenopausal women and testosterone administration to hypogonadal men also led to an increase in both $20 \mathrm{~K}$ - and $22 \mathrm{~K}-\mathrm{GH}$ isoforms, but did not alter the 20-to-22 K-GH ratio [36]. The latter study used specific immunoassays to measure the $20 \mathrm{~K}$ - and $22 \mathrm{~K}$-isoforms separately.

In summary, though the exercise induced increase in $\mathrm{GH}$ is known since a long time and has convincingly been demonstrated by several groups, any potential alterations in the relative abundance of the different isoforms have never been uniformly shown across studies. The use of different in-house research-type assay methodologies to measure concentrations of isoforms makes it very difficult directly comparing results from different studies. However, regardless of the assay methods used, the changes in isoform composition with exercise - if any - were small and of short duration.

\section{Doping}

Although evidence supporting performance enhancing effects in healthy trained subjects are lacking, it is known that GH is abused by some athletes [47]. For this reason, the World Anti-Doping Agency (WADA) classifies GH as a prohibited substance. Detection of GH doping, however, was considered I possible for a long time because recombinant $\mathrm{GH}$ is identical in its amino acid sequence and physicochemical properties to the main isoform of endogenous $\mathrm{GH}$. The pulsatile secretion pattern of $\mathrm{GH}$ also makes it impossible to use high serum $\mathrm{GH}$ levels as evidence for exogenous $\mathrm{GH}$ administration. The improved understanding of the physiology of $\mathrm{GH}$ isoforms and their regulation by the administration of the other $\mathrm{GH}$ isoforms, however, has helped to develop a valid doping test. It has been shown that administration of the $20 \mathrm{~K}-\mathrm{GH}$ isoform reduces secretion of the $22 \mathrm{~K}-\mathrm{GH}$ isoform levels [48]. In turn, administration of exogenous recombinant 22 K-GH administration rapidly suppresses non-22 K- and $20 \mathrm{~K}-\mathrm{GH}$ isoforms. Isoforms other than $22 \mathrm{~K}-\mathrm{GH}$ remain low for approximately $24 \mathrm{~h}$, coupled to a reduction in the $20 \mathrm{~K}$-to- $22 \mathrm{~K}-\mathrm{GH}$ ratio $[36,49,50]$. This knowledge enabled the development of the so-called GH isoform test as one WADA's recommended anti-doping tests [51, 52]. Its advantage is the direct detection of the molecular changes induced by the administration of recombinant $\mathrm{GH}$, although the short time window limits its use to the first 12-36 $\mathrm{h}$ after recombinant $\mathrm{GH}$ administration.

\section{Pathological conditions Acromegaly}

In acromegaly, the rhythmicity of GH secretion seems to be preserved [34]. There were some studies evaluating the $\mathrm{GH}$ isoforms in acromegaly in the past decades, although the studies used different methods and measured different isoform fractions. Boguszewski et al. [53] evaluated the "non-22 K-GH isoform" in men with acromegaly before and 1 year after transsphenoidal surgery. The relative abundance of the non-22 K-GH isoform was increased in active acromegaly when compared to inactive acromegaly and healthy controls. Interestingly, the proportion of non-22 K-GH isoform in active acromegaly remained high after non-curative surgery, while patients with controlled acromegaly achieved a percentage of the non-22 K-GH isoform similar to healthy individuals. Tsushima et al. [54] for the first time studied the $20 \mathrm{~K}-\mathrm{GH}$ isoform in acromegaly (by ELISA). They showed an increase of this isoform in active acromegaly, and also an increased 20- to $22 \mathrm{~K}-\mathrm{GH}$ ratio in acromegaly compared to healthy controls. Another group [36] studied GH secretion pattern in acromegaly and healthy controls by measuring $20 \mathrm{~K}$ - and $22 \mathrm{~K}-\mathrm{GH}$ every $20 \mathrm{~min}$ for $24 \mathrm{~h}$. Although there was an increase in $20 \mathrm{~K}-\mathrm{GH}$ isoform in patients with acromegaly, this isoform increased in parallel with $22 \mathrm{~K}-\mathrm{GH}$, keeping the 20- to $22 \mathrm{~K}-\mathrm{GH}$ ratio very similar to the ratio seen in healthy controls. There is also conflicting data regarding GH isoforms after somatostatin analogue treatment in patients with acromegaly. Although Murakami et al. did not find a modification in the 20 - to $22 \mathrm{~K}-\mathrm{GH}$ ratio after acute octreotide treatment [55], Leung et al. [36] described a rapid reduction in both isoforms, but with a relative increased in the 20- to $22 \mathrm{~K}-\mathrm{GH}$ isoform ratio. The authors speculate that this was caused by a shorter half-life and thus a faster decrease in the $22 \mathrm{~K}-\mathrm{GH}$ isoform when compared to the $20 \mathrm{~K}-\mathrm{GH}$ isoform. A more recent study [56] evaluated patients with acromegaly before and after 6 months of octreotide LAR treatment. The $20 \mathrm{~K}$ - and $22 \mathrm{~K}-\mathrm{GH}$ were increased in patients with acromegaly when compared to healthy controls, but the 20- to $22 \mathrm{~K}-\mathrm{GH}$ isoform proportion did not change. Furthermore, this study did not find alterations in the $20 \mathrm{~K}$ - to $22 \mathrm{~K}-\mathrm{GH}$ ratio before and 6 months after initiation of octreotide treatment. A limitation of this study was that only $13 \%(3 / 23)$ of acromegaly patients were controlled after octreotide treatment, precluding final conclusions about potential changes in the $20 \mathrm{~K}$ - to $22 \mathrm{~K}-\mathrm{GH}$ ratio related to octreotide therapy.

\section{GH deficiency}

GH deficiency obviously more likely is associated with very low GH concentrations. The very low concentrations provide a limitation to the study of $\mathrm{GH}$ isoforms, 
since the smaller, less abundant isoforms (eg. $20 \mathrm{~K}-\mathrm{GH}$ ) are even lower and commonly below the detection limit of most assays. Accordingly, there are only very few studies on $\mathrm{GH}$ isoform secretion in the $\mathrm{GH}$ deficiency field, and these studies also differ considerably in the analytical methods used. To overcome the problem, some of the studies used various stimulation test protocols to increase $\mathrm{GH}$ concentrations and make the isoforms accessible to existing analytical methods. Some studies reported no influence of age, pubertal stage and sex on the $20 \mathrm{~K} / 22 \mathrm{~K}-\mathrm{GH}$ ratio in normal and GH deficient children and adults. There was also no change in 24-h GH secretion pattern after arginine and hypoglycemia stimulation tests $[17,35,36]$. Another group studied normal children after a different stimulation test (GHRH). They found that both, the non-22 K-GH and $22 \mathrm{~K}-\mathrm{GH}$ isoforms increased after GHRH administration, but no change in the ratio. After a second GHRH stimulus, patients who still responded with a GH peak secretion greater than $10 \mathrm{ng} /$ $\mathrm{mL}$ had lower non-22 K-GH levels than non-responders. These data could suggest isoform related differences in the recovery of somatotrope function or differences in $\mathrm{GH}$ isoforms metabolic clearance, but also could be related to assay sensitivity [57]. Pagani et al. [41] studied $22 \mathrm{~K}$ - and $20 \mathrm{~K}-\mathrm{GH}$ isoforms in GH deficient patients before and after several pharmacologic stimuli such as arginine, L-dopa or glucagon. They found a significant increase in both 22- and $20 \mathrm{~K}-\mathrm{GH}$ isoforms, but describe a slight increase in the $22 \mathrm{~K}-/ 20 \mathrm{~K}-\mathrm{GH}$ ratio. The $22 \mathrm{~K}-\mathrm{GH}$ was the most abundant isoform even in a state of reduced GH secretion. As discussed above the use of different assays to assess GH isoforms could explain the difference in results. Furthermore, the groups studied different stimuli during dynamic tests.

\section{Prader-Willi syndrome}

Prader-Willi syndrome (PW) is a complex disorder associated to hypogonadism, behavioural and cognitive impairment, alongside with obesity and short stature. The GH secretion is abnormal, but the etiology is unknown. One study has evaluated GH isoforms in obese and non-obese, and GH deficient and non-GH deficient patients with PW submitted to GHRH plus arginine test [58]. There was no difference in the $22 \mathrm{~K}$ - and $20 \mathrm{~K}-\mathrm{GH}$ isoform ratio at baseline between obese and non-obese patients. The stimulation test increased $22 \mathrm{~K}$ - and $20 \mathrm{~K}-\mathrm{GH}$ isoforms in non-obese and non-GH deficient PW patients. The GH response for both isoforms was higher in non-obese $\mathrm{PW}$ patients and there was no difference in isoforms between $\mathrm{GH}$ deficient and non-GH deficient in these non-obese PW patients. The ratio of circulating levels of $22 \mathrm{~K}$-to-20 K-GH did not alter during the test in all studied groups. This study shows that alteration in GH isoforms generation may not be implicated in etiology of $\mathrm{GH}$ pattern alteration in PW [58]. Furthermore, this group compared GHRH plus arginine (GHRH+ARG) stimulation test with arginine (ARG) only in PW. Although both tests increased $20 \mathrm{~K}-\mathrm{GH}$ peak, it was higher in GHRH +ARG than in ARG group. This study further confirmed absence of alterations in the $20 / 22 \mathrm{~K}-\mathrm{GH}$ ratio in both stimulation tests [59].

\section{Other conditions}

Little data exist regarding GH isoforms in other conditions. One study showed that anorexia was associated with a higher abundance of the $20 \mathrm{~K}-\mathrm{GH}$ isoform $(20 \mathrm{~K} / 20 \mathrm{~K}-\mathrm{GH}+22 \mathrm{~K}-\mathrm{GH})$, but there was no difference in hypothyroidism, hyperthyroidism and non-insulin dependent diabetes [35].

\section{Impact of molecular heterogeneity on GH measurement in clinical routine}

The study of GH isoforms in physiology and in pathologic states was only possible with the development of more sensitive, isoform specific assays. Historically, GH has been measured by a wide spectrum of different analytical methods ranging from bioassays to radio receptor assays, immunoassays and mass spectrometry approaches. For a long time, isoform specificity on most methods was unknown, and for many assays used in clinical routine it is still unknown. Cell based and radio receptor assays do not distinguish specifically between isoforms, while mass spectrometry assays today still lack sensitivity particularly to measure the less abundant isoforms. Mass spectrometry assays also not used in clinical routine. The most commonly used method to assess GH concentrations in clinical routine are antibody-based immunoassays. Theoretically, detailed investigation of the epitopes recognized by the antibodies used in these assays would allow characterization of each assays isoform specificity. In fact, most of the studies on regulation of GH isoforms reviewed above have used some well-characterized isoform specific immunoassays. However, for GH assays used in high throughput routine laboratories the extra effort to characterize the isoform specificity of the assays is rarely done. However, it is important to be aware that each of this routine GH immunoassay - depending on the antibodies used - will pick a different spectrum of total GH isoforms. Many factors potentially affecting comparability of GH immunoassay have been described. These include nature and composition of the assay calibrator, interference from the growth hormone binding protein (GHBP) and also matrix effects. However, the differential recognition of GH isoforms remains one of the key problems of assay comparability. It inherently leads to issues regarding the quantification of $\mathrm{GH}$ and contributes to the known discrepancies between GH concentrations in a given sample obtained from measurements by different assays. 
Generally, older assays based on polyclonal antibodies commonly measured a broader isoform spectrum. The advent of monoclonal antibody assays brought more specificity to one or few of GH isoforms. It has been described that this increased specificity led to greater differences between the absolute concentrations reported from assays using different antibodies. Because of the recognition of only a certain spectrum of isoforms, the newer, monoclonal antibody based assays also have a tendency to report lower GH concentrations compared to older assays using polyclonal antisera. This is important to keep in mind when applying cut-offs from guidelines to the interpretation of GH data: If cut-offs were established by polyclonal assays, but in clinical routine today monoclonal antibody based assays are in use, the cut-offs might have to be adapted to reflect the lower $\mathrm{GH}$ concentrations reported by modern $\mathrm{GH}$ assays.

To facilitate the uniform adoption of cut-offs from guidelines continued efforts have been undertaken to harmonize results from different immunoassays for $\mathrm{GH}$. General recommendations for performance characteristics of ideal GH assays have been published by scientific societies to guide physicians working in the field [1-3].

\section{Isoform specificity for common assays}

The existence of GH isoforms affects the comparability of GH assays in two ways: As described above, different assays recognize different isoforms. In addition to this, different reference preparations are in use to calibrate the GH assays - the older ones consisting of a mixture of pituitary GH isoforms, the newer ones - of recombinant origin - consisting of the $22 \mathrm{~K}-\mathrm{GH}$ isoform only. In an immunoassay, the analyte concentration is determined by comparing the signal generated in the sample to a signal from samples with known amounts of the analyte. Consequently, the preparation used for $\mathrm{GH}$ assay standard curve has an important impact on GH measurement and results. In the past, the $\mathrm{GH}$ assays were done with pituitary extracts, and international reference preparations (IRP) were 66/217 and 80/505. Both contained a variety of GH isoforms and the exact amount of GH was unknown. The concentrations were arbitrarily assigned as 2.0 and $2.6 \mathrm{U} / \mathrm{mg}$ for IRP $66 / 217$ and 80 / 505 , respectively. Subsequently, new reference preparations were produced by recombinant technologies. These reference preparations consist of the $22 \mathrm{~K}-\mathrm{GH}$ exclusively (IRP 88/624 and 98/574). Now it became possible to make $\mathrm{GH}$ assays traceable to a mass unit of the IRP 88/624 (micrograms per liter). For historic reasons, a conventional unit was also assigned $(3.0 \mathrm{U} / \mathrm{mg})$, though recent guidelines do no longer support the use of conventional units. Recently, the next generation of the recombinant international IRP has been introduced (98/574). Basically identical to $88 / 624$, the new preparation is of high purity ( $>96 \% 22 \mathrm{~K}-\mathrm{GH}$ ) and shows adequate stability, bioactivity and availability [2].

Table 1 lists a number of GH immunoassays commonly used in clinical routine. All these assays meanwhile are calibrated to the recombinant IRP 98/574. Though the use of a common calibrator has slightly improved assay agreement over the last years [60], there is still considerable disagreement between GH assay results, and the disagreement still has considerable impact on the diagnosis of $\mathrm{GH}$ related disorders [61]. For many of the assays information on isoform specificity of the antibodies is not available or incomplete. One of the assays with published characterization of the antibodies (IDS) does not cross-react with an artificial GH isoform: pegvisomant is a mutated $\mathrm{GH}$ molecule, which is used as a drug to treat $\mathrm{GH}$ excess (acromegaly) by blocking the $\mathrm{GH}$ receptor. Most other available $\mathrm{GH}$ assays cross-react with pegvisomant, leading to falsely high or low results depending on antibody specificity and assay design.

\section{Data on clinical impact}

The variability of GH secretion itself, the lack of a perfect correlation with other biochemical markers like IGF-I and other factors make the evaluation of disease amelioration and remission in GH related diseases challenging [62-65]. Problems with standardization or harmonization of $\mathrm{GH}$ assays add to the complexity and make the applicability of international guidelines difficult. Therefore, improvements in the assay agreement could help to permit comparability of published data and the clinical use of the information. For the clinician it is important to realize and understand the potential impact of assay problems on $\mathrm{GH}$ assay results to allow interpretation of local results in relation to published cut-offs and recommendations.

\section{Acromegaly}

There are increasing data regarding the use of criteria for GH in the diagnosis of acromegaly [66]. Recommendations about the cut-off for GH during OGTT (oral glucose tolerance test) changed over time, with more recent publications recommending a nadir of $0.4 \mathrm{ng} / \mathrm{mL}$ or $1 \mathrm{ng} / \mathrm{mL}$ to exclude acromegaly and evaluate remission. In 2000, the "Cortina criteria" recommended a random GH concentration below $0.4 \mathrm{ng} / \mathrm{mL}$ or a $\mathrm{GH}$ nadir during OGTT below $1 \mathrm{ng} / \mathrm{mL}$, together with normal IGF-I for age and sex [67]. After a decade, another consensus statements for "controlled acromegaly" recommended different GH cut-off values together with normal IGF-I. The recommendation stated a random GH concentration below $1 \mathrm{ng} / \mathrm{mL}$ and a GH nadir below $0.4 \mathrm{ng} / \mathrm{mL}$. The current Endocrine Society Clinical Practice Guideline [68] requests the lack of suppression of $\mathrm{GH}$ below $1 \mathrm{ng} / \mathrm{mL}$ (and elevated IGF-I for age and sex) for diagnosing acromegaly. The suggested therapeutic 
Table 1 Characteristics of commonly used commercial assays for GH (according to manufacturers instructions/kit inserts available to the authors or according to published data). Calibration has changed for several assays in recent years, and the process is ongoing. To the best of the authors knowledge the assays listed here have uniformly adopted the latest recombinant standard for all countries. The list of assays is not complete. Additional hGH assays exist, including an unknown number of in-house assays. (modified from [3]

\begin{tabular}{|c|c|c|c|c|c|c|c|}
\hline Manufacturer & Name & Assay principle & Calibration & $\begin{array}{l}\text { Isoform- } \\
\text { specificity }\end{array}$ & Measuring range & $\begin{array}{l}\text { Recommended } \\
\text { sample material }\end{array}$ & Comment \\
\hline Siemens & Immulite 2000 & $\begin{array}{l}\text { Two-site } \\
\text { Chemilumminescent } \\
\text { immunometric assay }\end{array}$ & $98 / 574$ & $\begin{array}{l}\text { Not } \\
\text { provided }\end{array}$ & $\begin{array}{l}0.05 \text { to } 40 \mathrm{ng} / \mathrm{mL} \\
\text { Analytical sensitivity: } \\
0.01 \mathrm{ng} / \mathrm{mL}\end{array}$ & Serum & $\mathrm{ng} / \mathrm{mL} \times 3.0 \rightarrow \mathrm{mlU} / \mathrm{L}$ \\
\hline Diasorin & Liaison hGH & $\begin{array}{l}\text { Chemiluminescent } \\
\text { sandwich } \\
\text { immunoassay }\end{array}$ & $98 / 574$ & $\begin{array}{l}\text { Not } \\
\text { provided }\end{array}$ & 0.009-80 ng/mL & Serum & \\
\hline $\begin{array}{l}\text { Beckmann- } \\
\text { Coulter }\end{array}$ & $\begin{array}{l}\text { Access } \\
\text { Ultrasensitive } \\
\text { hGH }\end{array}$ & $\begin{array}{l}\text { Automated } \\
\text { immunometric assay, } \\
\text { Chemiluminescence }\end{array}$ & $98 / 574$ & $\begin{array}{l}\text { See } \\
\text { comment }\end{array}$ & $\begin{array}{l}0.002-35 \mathrm{ng} / \mathrm{mL} \\
(\mu / \mathrm{L})\end{array}$ & $\begin{array}{l}\text { Serum or } \\
\text { plasma } \\
\text { (heparin) }\end{array}$ & $\begin{array}{l}\text { Cross reaction analysed with } \\
\text { GH } 8 \mathrm{ng} / \mathrm{mL} \text { for } 20 \mathrm{~K}-\mathrm{GH} \text { : } \\
-2542 \%\end{array}$ \\
\hline IDS & iSYS hGH & $\begin{array}{l}\text { Chemilumminescent } \\
\text { assay }\end{array}$ & $98 / 574$ & $\begin{array}{l}22 \mathrm{kD} \text { GH: } \\
100 \%\end{array}$ & $0.05-100 \mathrm{ng} / \mathrm{mL}$ & $\begin{array}{l}\text { Serum or } \\
\text { plasma } \\
\text { (heparin or EDTA) }\end{array}$ & $\begin{array}{l}\text { Do not cross react with } \\
\text { substances in these } \\
\text { concentrations: } 20 \mathrm{~K}-\mathrm{GH} \\
(10 \mathrm{ng} / \mathrm{mL}) ; \text { placental } \mathrm{GH} \\
(200 \mathrm{ng} / \mathrm{mL}) ; \mathrm{HPL} \\
(10,000 \mathrm{ng} / \mathrm{mL}) ; \text { prolactin } \\
(40.000 \mathrm{ng} / \mathrm{mL}) ; \text { pegvisomant } \\
(50,000 \mathrm{ng} / \mathrm{mL}) ; \text { biotin } \\
300 \mathrm{nmol} / \mathrm{L}) ; \mathrm{GHBP}: 140 \\
\mathrm{ng} / \mathrm{mL} . \mathrm{ng} / \mathrm{mL} \times 3.0=\mu \mathrm{lU} / \mathrm{mL}\end{array}$ \\
\hline \multirow[t]{2}{*}{ DIASource } & hGH IRMA & $\begin{array}{l}\text { Immunometric assay } \\
\text { enzyme amplified } \\
\text { sensitivity }\end{array}$ & $98 / 574$ & $\begin{array}{l}\text { Not } \\
\text { provided }\end{array}$ & $\begin{array}{l}\text { 1-120 ng/mL } \\
\text { Sensitivity: ng/mL }\end{array}$ & Serum, plasma & $\begin{array}{l}\text { Conversion factor: } \\
1 \mu \mathrm{UU}=0.33 \mathrm{ng}\end{array}$ \\
\hline & hGH EASIA & $\begin{array}{l}\text { Enzyme- } \\
\text { Immunoassay }\end{array}$ & $98 / 574$ & $\begin{array}{l}\text { Not } \\
\text { provided }\end{array}$ & $\begin{array}{l}0.45-98 \mathrm{ng} / \mathrm{mL} \\
\text { Sensitivity:0.17 } \\
\mathrm{ng} / \mathrm{mL}\end{array}$ & Serum, plasma & $\begin{array}{l}\text { Conversion factor: } \\
1 \mu \mathrm{UU}=0.33 \mathrm{ng}\end{array}$ \\
\hline CisBio & hGH-RIACT & Immunoradiometric & $98 / 574$ & $\begin{array}{l}\text { Not } \\
\text { provided }\end{array}$ & $0.03-75 \mathrm{ng} / \mathrm{mL}$ & Serum & $\begin{array}{l}1 \mathrm{ng}=3 \mu \mathrm{UU} \text {; do not cross } \\
\text { react with prolactin and } \mathrm{hPL} \text {. } \\
\text { Cross reaction with } 20 \mathrm{kD} \mathrm{GH} \\
\text { is less than } 5 \% \text { for the } \\
\text { concentration up to } 3750 \\
\mathrm{ng} / \mathrm{mL}(22 \mathrm{kD} \mathrm{GH} \text { proportional } \\
\text { concentration above } 24,000 \\
\mathrm{ng} / \mathrm{mL} \text { ) }\end{array}$ \\
\hline
\end{tabular}

goal was a random $\mathrm{GH}$ below $1 \mathrm{ng} / \mathrm{mL}$ coupled to a normal age-adjusted IGF-I. In part, the differences in the published cut-offs are related to differences in the assays used, although most guidelines do not specify the assay used to generate the GH concentrations stated. Some authors have published convincing evidence that prevalence of acromegaly as well as percentages for remission largely depend on cut-off values used [60, 61, 64, 65, 69, 70]. More recent publications on studies using modern, more specific GH assays calibrated against the latest recombinant standard clearly indicated that the above mentioned cut.-off of $1 \mathrm{ng} / \mathrm{mL}$ is inappropriately high and should be adapted for modern assays. The use of the "traditional" cut-off of $1 \mathrm{ng} / \mathrm{mL}$ can contribute to a delayed diagnosis in patients with milder forms of acromegaly. Using such assays, in cases of mild acromegaly GH can be suppressed to concentrations significantly below $1 \mathrm{ng} / \mathrm{mL}$ [65]. Apart from the fact that different assays have different sensitivity and therefore, different limits of quantification, it must be kept in mind that different assays also do measure different - though for most assays unspecified or unknown - subgroups of $\mathrm{GH}$ isoforms. Although the $22 \mathrm{~K}-\mathrm{GH}$ is the most abundant and biological active isoform, in borderline cases the degree of specificity of the assay for the $22 \mathrm{~K}-\mathrm{GH}$ or other isoforms could significantly affect the classification of the patient [71]. It is important to keep this in mind when applying cut-offs from guideline in such cases in clinical practice. A better standardization of $\mathrm{GH}$ assays is of great importance to facilitate diagnosis and to avoid misdiagnosis and insufficient treatment. In a complex disease like acromegaly undesirable consequences for patients have to be avoided. Uncertainties in monitoring the success of the sophisticated and expensive treatment options also have significant economic impacts to the health system. 
Obviously, in addition to analytical factors, biological variables must also be taken into account when interpreting GH concentrations measured during the biochemical workup of suspected acromegaly. As an example, it has been proposed to adjust GH cut-offs for OGTT for sex and BMI to increase sensitivity of the test in the detection of acromegaly [72, 73]. Furthermore, the presence of renal failure can make the exclusion of acromegaly challenging: In these patients, high baseline GH levels are observed due to GH resistance - including an increase in the 20KD GH isoform [74]. The reduction in GH levels following oral glucose load might also be compromised. Although the literature is scarce, a case report on the exclusion of acromegaly in a patient with renal failure suggested that diagnosis must be made following dialysis: Baseline GH levels were lower compared to the situation before dialysis, and GH suppression during OGTT was normal [74].

\section{GH deficiency}

Also in the diagnosis of GH deficiency biological variables like body mass index (BMI) can be important. Stimulation of GH by the insulin tolerance test might be affected only if BMI is greater than $35 \mathrm{~kg} / \mathrm{m}^{2}$, but response to GHRH + arginine test generally has to be evaluated with cut-offs adjusted to BMI. Some authors advocate reducing the cut-off when the glucagon test is used in overweight/obese adults $[69,75]$. Age and the stimulus used should also be considered as factors interfering with test interpretation [76, 77]. However, besides these interfering biological factors, it is important to recognize that different $\mathrm{GH}$ assays can reveal different $\mathrm{GH}$ concentrations in the same sample. Therefore, cut-offs need to be adjusted in an assay specific manner. Lower cut-off values are expected with the current recommended IS 98/574 when compared with the IS 80/ 505 [78], reflecting differences in isoform composition of the calibrators. Wagner et al. [76] analyzed samples from several stimulation tests in short children with and without GHD by distinct GH assays and proposed different cut-off values depending on the GH assay used. Such assay specific data are required for each $\mathrm{GH}$ assay used to allow an unbiased interpretation of the stimulation test outcome (Table 2). Using "general" cut-offs frequently quoted in guidelines with no reference for a specific assay is associated with the risk of misinterpretation, potentially leading to over- or under treatment.

\section{Conclusion}

$\mathrm{GH}$ is a complex and heterogeneous mixture of molecular isoforms and not a single, homogenous molecule. Although $22 \mathrm{~K}-\mathrm{GH}$ is the main isoform in circulation, there are other $\mathrm{GH}$ isoforms that can represent approximately $10-20 \%$ of $\mathrm{GH}$ under physiological conditions.
Table 2 Cut-off limits derived from the same cohort of short children with different GH assays (adapted from reference [76])

\begin{tabular}{ll}
\hline Assay & Cut off limit $(\mathrm{ng} / \mathrm{mL})$ \\
\hline Immulite 2000 (Siemens) & 7.77 \\
AutoDELFIA (Perkin-Elmer) & 7.44 \\
iSYS (IDS) & 7.09 \\
Liaison (DIASorin) & 6.25 \\
RIA (in-house Tübingen) & 5.28 \\
DXI (Beckmann-Coulter) & 5.15 \\
ELISA (Mediagnost) & 5.14 \\
BC-IRMA (Beckmann-Coulter) & 4.32 \\
\hline
\end{tabular}

Usually, GH isoforms are secreted in parallel in response to various stimuli, with changes in $22 \mathrm{~K}-\mathrm{GH}$ mirroring changes in all isoforms. Some studies have reported minor changes in the non- $22 \mathrm{~K} / 22 \mathrm{~K}-\mathrm{GH}$ and $22 \mathrm{~K} /$ $20 \mathrm{~K}-\mathrm{GH}$ ratio under certain conditions, mostly with elevated abundance of the non- $22 \mathrm{~K}$ isoforms. Such variation might be due to differences in the half-life of the isoforms, but might also be related to limitations in current assay methods to accurately quantify the various isoforms over a wide concentration range. More studies are needed to better understand why some diseases including pituitary adenomas might lead to changes in the isoform ratios, and to evaluate if changes in isoforms might be of clinical relevance. More importantly in clinical routine, the existence of $\mathrm{GH}$ isoforms represents one of the main reasons for discrepancies in GH concentrations measured by different common GH assays. Efforts to harmonize GH assays are under way but it remains important for the clinician to understand the potential impact of the specific GH assay used on the $\mathrm{GH}$ concentrations reported. Clinical decision limits and cut-off values not only must be adapted to biological variables, but also to the specific $\mathrm{GH}$ assay used by the local laboratory.

Funding

CNPq and FAPEMIG: AROJr, CAPES: JROLS.

Availability of data and materials

Requested permission for Fig. 1.

Authors' contributions

The first author wrote the manuscript, and the second and third authors contributed in reviewing and editing the manuscript. All authors read and approved the final manuscript.

Ethics approval and consent to participate

Non applicable

Consent for publication

Non applicable

Competing interests

The authors declare that they have no competing interests. 


\section{Publisher's Note}

Springer Nature remains neutral with regard to jurisdictional claims in published maps and institutional affiliations.

\begin{abstract}
Author details
'Endocrinology Laboratory of Federal University of Minas Gerais. Alfredo Balena, 190, Santa Efigênia, Belo Horizonte 30130-100, Brazil. Endocrine Laboratory, Medizinische Klinik und Poliklinik IV, Klinikum der Universität München, Ziemssenstraße 1, 80336 Munich, Germany.
\end{abstract}

\section{Received: 1 June 2018 Accepted: 19 August 2018} Published online: 28 August 2018

\section{References}

1. Clemmons DR. Consensus statement on the standardization and evaluation of growth hormone and insulin-like growth factor assays. Clin Chem. 2011;57:555-9.

2. Wieringa GE, Sturgeon CM, Trainer PJ. The harmonisation of growth hormone measurements: taking the next steps. Clin Chim Acta. 2014;432:68-71.

3. Bidlingmaier M, Freda PU. Measurement of human growth hormone by immunoassays: current status, unsolved problems and clinical consequences. Growth Hormon IGF Res. 2010;20:19-25.

4. Popii V, Baumann G. Laboratory measurement of growth hormone. Clin Chim Acta. 2004;350:1-16.

5. Chen EY, Liao YC, Smith DH, Barrera-Saldana HA, Gelinas RE, Seeburg PH. The human growth hormone locus: nucleotide sequence, biology, and evolution. Genomics. 1989:4:479-97.

6. Ho Y, Liebhaber SA, Cooke NE. Activation of the human GH gene cluster: roles for targeted chromatin modification. Trends Endocrinol Metab. 2004;15:40-5.

7. Lecomte CM, Renard A, Martial JA. A new natural hGH variant--17.5 kd-produced by alternative splicing. An additional consensus sequence which might play a role in branchpoint selection. Nucleic Acids Res. 1987;15:6331-48.

8. Lewis UJ, Singh RN, Bonewald LF, Seavey BK. Altered proteolytic cleavage of human growth hormone as a result of deamidation. J Biol Chem. 1981;256:11645-50

9. Bustamante JJ, Gonzalez L, Carroll CA, Weintraub ST, Aguilar RM, Munoz J, Martinez AO, Haro LS. O-Glycosylated 24 kDa human growth hormone has a mucin-like biantennary disialylated tetrasaccharide attached at Thr-60. Proteomics. 2009;9:3474-88.

10. Baumann GP. Growth hormone isoforms. Growth Hormon IGF Res. 2009;19:333-40.

11. Wada M, Ikeda M, Takahashi Y, Asada N, Chang KT, Takahashi M, Honjo M. The full agonistic effect of recombinant $20 \mathrm{kDa}$ human growth hormone (hGH) on $\mathrm{CHO}$ cells stably transfected with hGH receptor cDNA. Mol Cell Endocrinol. 1997:133:99-107.

12. Tsunekawa B, Wada M, Ikeda M, Uchida H, Naito N, Honjo M. The 20kilodalton $(\mathrm{kDa})$ human growth hormone $(\mathrm{hGH})$ differs from the 22-kDa $\mathrm{hGH}$ in the effect on the human prolactin receptor. Endocrinology. 1999:140:3909-18.

13. Solomon G, Reicher S, Gussakovsky EE, Jomain JB, Gertler A. Large-scale preparation and in vitro characterization of biologically active human placental (20 and 22K) and pituitary (20K) growth hormones: placental growth hormones have no lactogenic activity in humans. Growth Hormon IGF Res. 2006:16:297-307.

14. Wada M, Uchida H, Ikeda M, Tsunekawa B, Naito N, Banba S, Tanaka E, Hashimoto Y, Honjo M. The 20-kilodalton ( $\mathrm{kDa}$ ) human growth hormone $(\mathrm{hGH})$ differs from the 22-kDa hGH in the complex formation with cell surface $\mathrm{hGH}$ receptor and $\mathrm{hGH}$-binding protein circulating in human plasma. Mol Endocrinol. 1998;12:146-56.

15. Ishikawa M, Tachibana T, Kamioka T, Horikawa R, Katsumata N, Tanaka T. Comparison of the somatogenic action of $20 \mathrm{kDa}$ - and $22 \mathrm{kDa}$-human growth hormones in spontaneous dwarf rats. Growth Hormon IGF Res. 2000;10:199-206.

16. Satozawa N, Takezawa K, Miwa T, Takahashi S, Hayakawa M, Ooka H. Differences in the effects of $20 \mathrm{~K}$ - and $22 \mathrm{~K}-\mathrm{hGH}$ on water retention in rats. Growth Hormon IGF Res. 2000;10:187-92.

17. Ishikawa M, Yokoya S, Tachibana K, Hasegawa Y, Yasuda T, Tokuhiro E, Hashimoto Y, Tanaka T. Serum levels of 20-kilodalton human growth hormone $(\mathrm{GH})$ are parallel those of 22-kilodalton human $\mathrm{GH}$ in normal and short children. J Clin Endocrinol Metab. 1999:84:98-104.

18. Yao-Xia L, Jing-Yan C, Xia-Lian T, Ping C, Min Z. The 20kDa and 22kDa forms of human growth hormone $(\mathrm{hGH})$ exhibit different intracellular signalling profiles and properties. Gen Comp Endocrinol. 2017;248:49-54.
19. De Palo EF, De Filippis V, Gatti R, Spinella P. Growth hormone isoforms and segments/fragments: molecular structure and laboratory measurement. Clin Chim Acta. 2006;364:67-76

20. Such-Sanmartin G, Bosch J, Segura J, Wu M, Du H, Chen G, Wang S, VilaPerello M, Andreu D, Gutierrez-Gallego R. Characterisation of the 5 kDa growth hormone isoform. Growth Factors. 2008;26:152-62.

21. Miletta MC, Lochmatter D, Pektovic $V$, Mullis PE. Isolated growth hormone deficiency type 2: from gene to therapy. Endocr Dev. 2012;23:109-20.

22. Hettiarachchi M, Watkinson A, Leung KC, Sinha YN, Ho KK, Kraegen EW. Human growth hormone fragment (hGH44-91) produces insulin resistance and hyperinsulinemia but is less potent than $22 \mathrm{kDa} \mathrm{hGH}$ in the rat. Endocrine. 1997;6:47-52.

23. Sinha YN, Jacobsen BP. Human growth hormone (hGH)-(44-191), a reportedly diabetogenic fragment of hGH, circulates in human blood: measurement by radioimmunoassay. J Clin Endocrinol Metab. 1994;78:1411-8.

24. Sinha YN, Jacobsen BP, Lewis UJ. Antibodies to newly recognized murine 13-18 KDa pituitary peptides crossreact with growth hormone and prolactin from several species, including man. Biochem Biophys Res Commun. 1989;163:386-93.

25. Pradhananga S, Wilkinson I, Ross RJ. Pegvisomant: structure and function. J Mol Endocrinol. 2002;29:11-4.

26. Kopchick JJ. Discovery and mechanism of action of pegvisomant. Eur J Endocrinol. 2003;148(Suppl 2):S21-5.

27. Kopchick JJ, Parkinson C, Stevens EC, Trainer PJ. Growth hormone receptor antagonists: discovery, development, and use in patients with acromegaly. Endocr Rev. 2002;23:623-46.

28. Ng FM, Jiang WJ, Gianello R, Pitt S, Roupas P. Molecular and cellular actions of a structural domain of human growth hormone (AOD9401) on lipid metabolism in Zucker fatty rats. J Mol Endocrinol. 2000;25:287-98.

29. Heffernan MA, Jiang WJ, Thorburn AW, Ng FM. Effects of oral administration of a synthetic fragment of human growth hormone on lipid metabolism. Am J Physiol Endocrinol Metab. 2000;279:E501-7.

30. Bustamante JJ, Grigorian AL, Munoz J, Aguilar RM, Trevino LR, Martinez AO, Haro LS. Human growth hormone: $45-\mathrm{kDa}$ isoform with extraordinarily stable interchain disulfide links has attenuated receptor-binding and cellproliferative activities. Growth Hormon IGF Res. 2010;20:298-304.

31. Boguszewski CL, Svensson PA, Jansson T, Clark R, Carlsson LM, Carlsson B. Cloning of two novel growth hormone transcripts expressed in human placenta. J Clin Endocrinol Metab. 1998:83:2878-85.

32. Vickers MH, Gilmour S, Gertler A, Breier BH, Tunny K, Waters MJ, Gluckman PD. 20-kDa placental hGH-V has diminished diabetogenic and lactogenic activities compared with 22-kDa hGH-N while retaining antilipogenic activity. Am J Physiol Endocrinol Metab. 2009;297:E629-37.

33. Surya S, Symons K, Rothman E, Barkan AL. Complex rhythmicity of growth hormone secretion in humans. Pituitary. 2006;9:121-5.

34. Ribeiro-Oliveira A Jr, Abrantes MM, Barkan AL. Complex rhythmicity and age dependence of growth hormone secretion are preserved in patients with acromegaly: further evidence for a present hypothalamic control of pituitary somatotropinomas. J Clin Endocrinol Metab. 2013;98:2959-66.

35. Tsushima $T$, Katoh $Y$, Miyachi $Y$, Chihara $K$, Teramoto A, Irie M, Hashimoto $Y$. Serum concentrations of 20K human growth hormone in normal adults and patients with various endocrine disorders. Study Group of 20K hGH. Endocr J. 2000;47(Suppl):S17-21

36. Leung KC, Howe C, Gui LY, Trout G, Veldhuis JD, Ho KK. Physiological and pharmacological regulation of 20-kDa growth hormone. Am J Physiol Endocrinol Metab. 2002;283:E836-43.

37. Baumann G, Stolar MW, Buchanan TA. Slow metabolic clearance rate of the 20,000-Dalton variant of human growth hormone: implications for biological activity. Endocrinology. 1985;117:1309-13.

38. Nindl BC, Kraemer WJ, Marx JO, Tuckow AP, Hymer WC. Growth hormone molecular heterogeneity and exercise. Exerc Sport Sci Rev. 2003;31:161-6.

39. Tuckow AP, Rarick KR, Kraemer WJ, Marx JO, Hymer WC, Nindl BC. Nocturnal growth hormone secretory dynamics are altered after resistance exercise: deconvolution analysis of 12-hour immunofunctional and immunoreactive isoforms. Am J Physiol Regul Integr Comp Physiol. 2006:291:R1749-55.

40. Wallace JD, Cuneo RC, Bidlingmaier M, Lundberg PA, Carlsson L, Boguszewski CL, Hay J, Healy ML, Napoli R, Dall R, Rosen T, Strasburger CJ. The response of molecular isoforms of growth hormone to acute exercise in trained adult males. J Clin Endocrinol Metab. 2001;86:200-6.

41. Pagani S, Cappa M, Meazza C, Ubertini G, Travaglino P, Bozzola E, Bozzola M Growth hormone isoforms release in response to physiological and pharmacological stimuli. J Endocrinol Investig. 2008;31:520-4. 
42. Kraemer WJ, Nindl BC, Marx JO, Gotshalk LA, Bush JA, Welsch JR, Volek JS, Spiering BA, Maresh CM, Mastro AM, Hymer WC. Chronic resistance training in women potentiates growth hormone in vivo bioactivity: characterization of molecular mass variants. Am J Physiol Endocrinol Metab. 2006;291:E1177-87.

43. Pierce JR, Tuckow AP, Alemany JA, Rarick KR, Staab JS, Harman EA, Nindl BC. Effects of acute and chronic exercise on disulfide-linked growth hormone variants. Med Sci Sports Exerc. 2009;41:581-7.

44. Hymer WC, Kraemer WJ, Nindl BC, Marx JO, Benson DE, Welsch JR, Mazzetti SA, Volek JS, Deaver DR. Characteristics of circulating growth hormone in women after acute heavy resistance exercise. Am J Physiol Endocrinol Metab. 2001;281:E878-87.

45. Kraemer WJ, Rubin MR, Hakkinen K, Nindl BC, Marx JO, Volek JS, French DN, Gomez AL, Sharman MJ, Scheett T, Ratamess NA, Miles MP, Mastro A, VanHeest J, Maresh CM, Welsch JR, Hymer WC. Influence of muscle strength and total work on exercise-induced plasma growth hormone isoforms in women. J Sci Med Sport. 2003;6:295-306.

46. Kraemer WJ, Nindl BC, Volek JS, Marx JO, Gotshalk LA, Bush JA, Welsch JR, Vingren JL, Spiering BA, Fragala MS, Hatfield DL, Ho JY, Maresh CM, Mastro AM, Hymer WC. Influence of oral contraceptive use on growth hormone in vivo bioactivity following resistance exercise: responses of molecular mass variants. Growth Hormon IGF Res. 2008;18:238-44.

47. Nelson AE, Ho KK. Abuse of growth hormone by athletes. Nat Clin Pract Endocrinol Metab. 2007;3:198-9.

48. Hashimoto Y, Kamioka T, Hosaka M, Mabuchi K, Mizuchi A, Shimazaki Y, Tsunoo M, Tanaka T. Exogenous 20K growth hormone (GH) suppresses endogenous 22K GH secretion in normal men. J Clin Endocrinol Metab. 2000;85:601-6.

49. Wallace JD, Cuneo RC, Bidlingmaier M, Lundberg PA, Carlsson L, Boguszewski CL, Hay J, Boroujerdi M, Cittadini A, Dall R, Rosen T, Strasburger $\mathrm{CJ}$. Changes in non-22-kilodalton $(\mathrm{kDa})$ isoforms of growth hormone $(\mathrm{GH})$ after administration of 22-kDa recombinant human $\mathrm{GH}$ in trained adult males. J Clin Endocrinol Metab. 2001;86:1731-7.

50. Keller A, Wu Z, Kratzsch J, Keller E, Blum WF, Kniess A, Preiss R, Teichert Strasburger CJ, Bidlingmaier M. Pharmacokinetics and pharmacodynamics of $\mathrm{GH}$ : dependence on route and dosage of administration. Eur J Endocrinol. 2007; 156:647-53.

51. Baumann GP. Growth hormone doping in sports: a critical review of use and detection strategies. Endocr Rev. 2012;33:155-86.

52. Bidlingmaier M, Suhr J, Ernst A, Wu Z, Keller A, Strasburger CJ, Bergmann A. High-sensitivity chemiluminescence immunoassays for detection of growth hormone doping in sports. Clin Chem. 2009;55:445-53.

53. Boguszewski $C L$, Johannsson $G$, Bengtsson BA, Johansson A, Carlsson B, Carlsson LM. Circulating non-22-kilodalton growth hormone isoforms in acromegalic men before and after transsphenoidal surgery. J Clin Endocrinol Metab. 1997:82:1516-21

54. Tsushima T, Katoh Y, Miyachi Y, Chihara K, Teramoto A, Irie M, Hashimoto Y. Serum concentration of $20 \mathrm{~K}$ human growth hormone $(20 \mathrm{~K} \mathrm{hGH})$ measured by a specific enzyme-linked immunosorbent assay. Study group of 20K hGH. J Clin Endocrinol Metab. 1999;84:317-22.

55. Murakami Y, Shimizu T, Yamamoto M, Kato Y. Serum levels of 20 kilodalton human growth hormone $(20 \mathrm{~K}-\mathrm{hGH})$ in patients with acromegaly before and after treatment with octreotide and transsphenoidal surgery. Endocr J. 2004:51:343-8.

56. Lima GA, Wu Z, Silva CM, Barbosa FR, Dias JS, Schrank Y, Strasburger CJ, Gadelha MR. Growth hormone isoforms in acromegalic patients before and after treatment with octreotide LAR. Growth Hormon IGF Res. 2010;20:87-92.

57. Coya R, Algorta J, Boguszewski CL, Vela A, Carlsson LM, Aniel-Quiroga A, Busturia MA, Martul P. Circulating non-22 kDa growth hormone isoforms after a repeated GHRH stimulus in normal subjects. Growth Hormon IGF Res. 2005:15:123-9.

58. Rigamonti AE, Grugni G, Marazzi N, Bini S, Bidlingmaier M, Sartorio A. Unaltered ratio of circulating levels of growth hormone/GH isoforms in adults with Prader-Willi syndrome after GHRH plus arginine administration. Growth Hormon IGF Res. 2015;25:168-73.

59. Rigamonti $A E$, Crino A, Bocchini S, Convertino A, Bidlingmaier M, Haenelt $M$, Tamini S, Cella SG, Grugni G, Sartorio A. GHRH plus arginine and arginine administration evokes the same ratio of $\mathrm{GH}$ isoforms levels in young patients with Prader-Willi syndrome. Growth Horm IGF Res. 2017;

60. Katsumata N, Shimatsu A, Tachibana K, Hizuka N, Horikawa R, Yokoya S, Tatsumi Kl, Mochizuki T, Anzo M, Tanaka T. Continuing efforts to standardize measured serum growth hormone values in Japan. Endocr J. 2016;63:933-6.

61. Kanakis GA, Chrisoulidou A, Bargiota A, Efstathiadou ZA, Papanastasiou L, Theodoropoulou A, Tigas SK, Vassiliadi DA, Tsagarakis S, Alevizaki M. The ongoing challenge of discrepant growth hormone and insulin-like growth factor I results in the evaluation of treated acromegalic patients: a systematic review and meta-analysis. Clin Endocrinol. 2016;85:681-8.

62. Casagrande $A$, Bronstein MD, Jallad RS, Moraes AB, Elias PC, Castro M, Czepielewski MA, Boschi A, Ribeiro-Oliveira A Jr, Schweizer JR, Vilar L, Nazato DM, Gadelha MR, Abucham J. All other investigators of the s. Long-term remission of acromegaly after octreotide withdrawal is an uncommon and frequently unsustainable event. Neuroendocrinology. 2017;104:273-9.

63. Ribeiro-Oliveira A Jr, Barkan A. The changing face of acromegaly--advances in diagnosis and treatment. Nat Rev Endocrinol. 2012;8:605-11.

64. Ribeiro-Oliveira A Jr, Faje A, Barkan A. Postglucose growth hormone nadir and insulin-like growth factor-1 in naive-active acromegalic patients: do these parameters always correlate? Arq Bras Endocrinol Metabol. 2011;55:494-7.

65. Ribeiro-Oliveira A Jr, Faje AT, Barkan AL. Limited utility of oral glucose tolerance test in biochemically active acromegaly. Eur J Endocrinol. 2011;164:17-22.

66. Abreu A, Tovar AP, Castellanos R, Valenzuela A, Giraldo CM, Pinedo AC, Guerrero DP, Barrera CA, Franco HI, Ribeiro-Oliveira A Jr, Vilar L, Jallad RS, Duarte FG, Gadelha M, Boguszewski CL, Abucham J, Naves LA, Musolino NR, de Faria ME, Rossato C, Bronstein MD. Challenges in the diagnosis and management of acromegaly: a focus on comorbidities. Pituitary. 2016;19:448-57.

67. Giustina A, Barkan A, Casanueva FF, Cavagnini F, Frohman L, Ho K, Veldhuis J, Wass J, Von Werder K, Melmed S. Criteria for cure of acromegaly: a consensus statement. J Clin Endocrinol Metab. 2000;85:526-9.

68. Katznelson L, Laws ER Jr, Melmed S, Molitch ME, Murad MH, Utz A, Wass JA, Endocrine S. Acromegaly: an endocrine society clinical practice guideline. J Clin Endocrinol Metab. 2014;99:3933-51.

69. Yuen KC, Tritos NA, Samson SL, Hoffman AR, Katznelson L. American Association of Clinical Endocrinologists and American College of endocrinology disease state clinical review: update on growth hormone stimulation testing and proposed revised cut-point for the glucagon stimulation test in the diagnosis of adult growth hormone deficiency. Endocr Pract. 2016;22:1235-44.

70. Freda PU, Nuruzzaman AT, Reyes CM, Sundeen RE, Post KD. Significance of "abnormal" nadir growth hormone levels after oral glucose in postoperative patients with acromegaly in remission with normal insulin-like growth factor-l levels. J Clin Endocrinol Metab. 2004;89:495-500.

71. Pokrajac A, Wark G, Ellis AR, Wear J, Wieringa GE, Trainer PJ. Variation in GH and IGF-I assays limits the applicability of international consensus criteria to local practice. Clin Endocrinol. 2007;67:65-70.

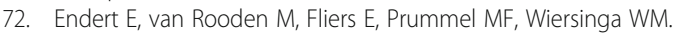
Establishment of reference values for endocrine tests--part $\mathrm{V}$ : acromegaly. Neth J Med. 2006;64:230-5.

73. Schilbach K, Strasburger CJ, Bidlingmaier M. Biochemical investigations in diagnosis and follow up of acromegaly. Pituitary. 2017;20:33-45.

74. Pena-Porta JM, Burgase-Estallo I, Nicolas-Sanchez F, Vicente-de Vera Floristan C. Chronic kidney disease and acromegaly: when appearances are deceptive. Nefrologia. 2014;34:800-2.

75. Feldt-Rasmussen U, Klose M. Adult Growth Hormone Deficiency Clinical Management. In: De Groot $\sqcup$, Chrousos G, Dungan K, Feingold KR, Grossman A, Hershman JM, Koch C, Korbonits M, Mc Lachlan R, New M, Purnell J, Rebar R, Singer F, Vinik A, editors. Endotext. South Dartmouth; 2000.

76. Wagner IV, Paetzold C, Gausche R, Vogel M, Koerner A, Thiery J, Arsene CG, Henrion A, Guettler B, Keller E, Kiess W, Pfaeffle R, Kratzsch J. Clinical evidencebased cutoff limits for $\mathrm{GH}$ stimulation tests in children with a backup of results with reference to mass spectrometry. Eur J Endocrinol. 2014;171:389-97.

77. Chinoy A, Murray PG. Diagnosis of growth hormone deficiency in the paediatric and transitional age. Best Pract Res Clin Endocrinol Metab. 2016;30:737-47.

78. Chaler EA, Ballerini G, Lazzati JM, Maceiras M, Frusti M, Bergada I, Rivarola MA, Belgorosky A, Ropelato G. Cut-off values of serum growth hormone $(\mathrm{GH})$ in pharmacological stimulation tests (PhT) evaluated in short-statured children using a chemiluminescent immunometric assay (ICMA) calibrated with the international recombinant human GH standard 98/574. Clin Chem Lab Med. 2013;51:e95-7. 